\title{
Tofacitinib: An Option for Acute Severe Ulcerative Colitis?
}

\author{
Sara Santos Verónica Gamelas Rita Saraiva Guilherme Simões \\ Joana Saiote Jaime Ramos \\ Centro Hospitalar de Lisboa Central, Lisbon, Portugal
}

Keywords

Acute severe ulcerative colitis · Tofacitinib

\section{Abstract}

Tofacitinib has emerged as a new option for ulcerative colitis. Its rapid absorption, metabolism, and clinical improvement make it an interesting option for rescue therapy in acute severe ulcerative colitis (ASUC), a situation with limited therapeutic options in patients with a long-term disease course and multiple drug failure. The management of ASUC in this setting becomes challenging, underlying the need for new drugs and data on their efficacy and safety. We describe 2 cases of acute episodes in which tofacitinib was used as a rescue therapy.

(c) 2021 Sociedade Portuguesa de Gastrenterologia Published by S. Karger AG, Basel

\section{Tofacitinib: uma opção na colite ulcerosa aguda grave?}

\section{Palavras Chave}

Colite ulcerosa grave $\cdot$ Tofacitinib

\section{Resumo}

O tofacitinib surgiu como uma nova terapêutica para a colite ulcerosa. A rapidez da sua absorção, metabolismo e melhoria clínica tornam-no uma opção apelativa como karger@karger.com www.karger.com/pjg

Karger

GOPEN ACCESS
(C) 2021 Sociedade Portuguesa de Gastrenterologia Published by S. Karger AG, Basel

This is an Open Access article licensed under the Creative Commons Attribution-NonCommercial-4.0 International License (CC BY-NC) (http://www.karger.com/Services/OpenAccessLicense), applicable to the online version of the article only. Usage and distribution for commercial purposes requires written permission. terapêutica de resgate na colite ulcerosa aguda grave (termo em inglês - ASUC), entidade esta com opções terapêuticas limitadas em doentes com longo curso de doença e falência prévia a múltiplos fármacos. A abordagem da ASUC neste contexto é desafiante, salientando-se a necessidade de novos fármacos e dados reais sobre a sua eficácia e segurança. Descrevemos dois casos de episódios agudos nos quais o tofacitinib foi utilizado como terapêutica de resgate.

C 2021 Sociedade Portuguesa de Gastrenterologia Publicado por S. Karger AG, Basel

\section{Introduction}

Acute severe ulcerative colitis (ASUC) remains a severe and challenging condition, with increased risk of colectomy. Rescue therapies for patients who fail corticosteroids include infliximab and calcineurin inhibitors [1]. However, these therapies often fail in patients with a long-term disease course, imposing the need for further options besides colectomy. Tofacitinib has emerged as a new therapy for ulcerative colitis, but there are few data regarding its efficacy and safety in cases of ASUC. Its rapid absorption, metabolism, and clinical improvement make it an interesting option for rescue therapy in ASUC.

S.S. is the guarantor of this article. 


\section{Case Description}

In 2019, at our institution, 8 patients started tofacitinib for moderate-to-severe ulcerative colitis. We report 2 cases in which tofacitinib was used as a rescue therapy option for ASUC.

Patient 1 was a 38 -year-old female and patient 2 was a 62 -yearold male, both of whom had pancolitis, previous episodes of ASUC, and failure to respond to at least 1 anti-TNFa agent, vedolizumab, and tacrolimus throughout their disease course. Disease duration was 11 and 29 years, respectively.

At admission, patient 1 presented with 10 bloody stools per day, C-reactive protein (CRP) $51.5 \mathrm{mg} / \mathrm{L}$, and calprotectin 779 $\mu \mathrm{g} / \mathrm{g}$; patient 2 complained of abdominal pain and had 8 bloody stools per day, CRP $56.4 \mathrm{mg} / \mathrm{L}$, and calprotectin 3,663 $\mu \mathrm{g} / \mathrm{g}$. Both patients had a total Mayo score of 11, including endoscopic stage 3. Clostridium difficile and CMV infection were ruled out at admission.

The last dose of biologic therapy had been infused in the 2 months before admission and at this time both patients were on oral prednisolone. Accordingly, intravenous methylprednisolone was administered for 5-7 days, i.e., the time required to obtain institutional approval for tofacitinib use, but also without significant improvement as evaluated with the Oxford criteria.

Tofacitinib was started at a dose of $10 \mathrm{mg}$ twice daily. After 5-7 days of therapy, the patients had 3-4 soft stools without any blood and complete resolution of abdominal pain. Upon discharge, CRP was $<10 \mathrm{mg} / \mathrm{L}$ in both patients. At week 8 after tofacitinib initiation, the total Mayo scores were 3 and 2, respectively. At week 16, both patients scored had a Mayo score of 1 and demonstrated endoscopic remission. Patient 1 is on a dose of $5 \mathrm{mg}$ twice daily. $\mathrm{Pa}$ tient 2 had a mild recrudescence of symptoms with $5 \mathrm{mg}$ twice daily, which has resolved with a dose increase. Currently, with 14 and 11 months of follow-up, they remain in steroid-free clinical remission, without readmission or colectomy. Finally, patient 2 required statin use for lowering total cholesterol which has rose after starting tofacitinib, with posterior normalization of blood values.

\section{Discussion}

Ulcerative colitis patients have a $20-30 \%$ risk of developing an acute severe episode requiring hospitalization in their disease course. Initial therapy with corticosteroids fails in $30 \%$ of cases, thus requiring rescue therapies which, according to current recommendations, include infliximab and calcineurin inhibitors [2]. However, we attest to an increasing number of patients with a long disease course and who have already failed anti-TNFa and other therapies. A primary nonresponse to biologics is reported in up to $30 \%$ of patients and a secondary nonresponse occurs in $10-20 \%$ per year, leading to a $15 \%$ rate of total proctocolectomy [1]. This highlights the need for additional treatment options for ASUC. Tofacitinib is a small molecule approved for use in moderate-to-severe ulcerative colitis, and its efficacy has been proven includ- ing in patients with previous failure to respond to other agents. Its pharmacokinetic profile, characterized by a rapid absorption and metabolism, together with a post hoc analysis of OCTAVE 1 and 2 showing a rapid clinical improvement by day 3 of therapy, has made this drug an appealing choice for rescue therapy in ASUC [3]. Since 2019, Berinstein et al. [4], using $30 \mathrm{mg}$ for 3 days, and Kotwani et al. [5], using the standard $10 \mathrm{mg}$ twice-daily dose, reported 8 cases in total of tofacitinib use for ASUC, with only 1 patient requiring colectomy. These results have led to a consideration of positioning of tofacitinib in the algorithm of ASUC approach as a second-line agent after intravenous steroid failure, in patients with previous exposure to anti-TNFa [6]. More recently, Honap et al. [7] reported a series of 7 patients receiving the standard dose, 4 of whom required colectomy, 2 during the index hospitalization and 2 after readmission within 90 days.

Our 2 cases represent the paradigm of long-standing relapsing disease, with a failure of all drug classes available at the time for rescue therapy. The decision to administer tofacitinib in the ASUC setting was multidisciplinary, and mostly based on its rapid onset of action as well as clearance, which theoretically minimize surgical complications in case of urgent colectomy.

Additionally, it is still to be defined the best option after a first rescue drug failure, i.e., a sequential therapy with a third drug or surgery. In this context, only 1 of the 15 patients reported in the literature was submitted to tofacitinib after infliximab failure in the same episode, with no reported side effects [7]. However, this strategy increases the risk of infection, and the worse outcomes resulting from a delayed surgery must be taken into account and discussed with the patient. Tofacitinib may be an effective second-line therapy for ASUC patients, although, due to lack of evidence, it should only be administered on a case-by-case basis after a multidisciplinary discussion about the risk-benefit ratio. Further highquality evidence is needed to validate the use of tofacitinib in ASUC.

\section{Statement of Ethics}

The patients were provided with a copy of the manuscript and signed a consent form to have their case published.

Conflict of Interest Statement

There were no conflicts of interest. 


\section{Funding Sources}

There was no funding.

\section{References}

1 D’Amico F, Parigi TL, Fiorino G, Peyrin-Biroulet $\mathrm{L}$, Danese $\mathrm{S}$. Tofacitinib in the treatment of ulcerative colitis: efficacy and safety from clinical trials to real-world experience. Therap Adv Gastroenterol. 2019;12:1-10.

2 Verdon C, Bessissow T, Lakatos PL. Management of Acute Severe Colitis in the Era of Biologicals and Small Molecules. J Clin Med. 2019 Dec;8(12):2169.

\section{Author Contributions}

All authors were involved in management of the patients. S.S. wrote the manuscript and collected the data. J.S. and J.R. edited the manuscript.
3 Hanauer S, Panaccione R, Danese S, Cheifetz A, Reinisch W, Higgins PD, et al. Tofacitinib Induction Therapy Reduces Symptoms within 3 Days for Patients with Ulcerative Colitis. Clin Gastroenterol Hepatol. 2019 Jan;17(1): 139-47.

4 Berinstein JA, Steiner CA, Regal RE, Allen JI, Kinnucan JA, Stidham RW, et al. Efficacy of Induction Therapy with High-Intensity Tofacitinib in 4 Patients with Acute Severe Ulcerative Colitis. Clin Gastroenterol Hepatol. 2019 Apr;17(5):988-990.e1.

5 Kotwani P, Terdiman J, Lewin S. Tofacitinib for Rescue Therapy in Acute Severe Ulcerative Colitis: A Real-world Experience. J Crohn's Colitis. 2020 Jul;14(7):1026-8.
6 D’Amico F, Peyrin-Biroulet L, Danese S. Tofacitinib for Acute Severe Colitis: When the Going Gets Tough, the Tough Get Going. J Crohn's Colitis. 2020 Jul;14(7):883-5.

7 Honap S, Pavlidis P, Ray S, Sharma E, Anderson S, Sanderson JD, et al. Tofacitinib in Acute Severe Ulcerative Colitis - A RealWorld Tertiary Center Experience. Inflamm Bowel Dis. 2020 Oct;26(11):e147-9. 